\title{
Durum Wheat Mediterranean Landraces: A Valuable Source for Resistance to Tan Spot Disease
}

\author{
Marwa Laribi ${ }^{1,2}$, Sarrah Ben M'Barek ${ }^{2,3, *}$, Moez Fakhfakh ${ }^{4}$, Amor Hassine Yahyaoui ${ }^{2,5}$ and Khaled Sassi $^{1}$ (D) \\ 1 LR14AGR01 Laboratory of Genetic and Cereal Breeding, National Agronomic Institute of Tunisia, \\ University of Carthage, Tunis 1082, Tunisia; mar.wa199@hotmail.fr (M.L.); khaledsassi1@gmail.com (K.S.) \\ 2 CRP Wheat Septoria Precision Phenotyping Platform, Tunis 1082, Tunisia; amor.yahyaoui@gmail.com \\ 3 Regional Field Crops Research Center of Beja (CRRGC) BP 350, Béja 9000, Tunisia \\ 4 Comptoir Multiservices Agricoles, 82, Avenue Louis Brailles, Tunis Belvédère, Tunis 1002, Tunisia; \\ moez.fakhfakh@rose-blanche.com \\ 5 International Maize and Wheat Improvement Center (CIMMYT), Km. 45, Carretera México-Veracruz, \\ El Batan, Texcoco 56130, Mexico \\ * Correspondence: sarrah_bm@msn.com
}

Citation: Laribi, M.; Ben M’Barek, S.; Fakhfakh, M.; Yahyaoui, A.H.; Sassi, K. Durum Wheat Mediterranean Landraces: A Valuable Source for Resistance to Tan Spot Disease. Agriculture 2021, 11, 1148. https:// doi.org/10.3390/agriculture11111148

Academic Editors: Kevin Begcy and Laramy Enders

Received: 23 August 2021

Accepted: 5 October 2021

Published: 16 November 2021

Publisher's Note: MDPI stays neutral with regard to jurisdictional claims in published maps and institutional affiliations.

Copyright: (c) 2021 by the authors. Licensee MDPI, Basel, Switzerland. This article is an open access article distributed under the terms and conditions of the Creative Commons Attribution (CC BY) license (https:// creativecommons.org/licenses/by/ $4.0 /)$.

\begin{abstract}
Tan spot (TS), caused by Pyrenophora tritici-repentis (Ptr), has gained significant importance in Tunisia. In this study, a Mediterranean durum wheat collection of 113 accessions were evaluated under field conditions, during the 2018-2019 cropping season, for resistance to Ptr at Koudia experimental station in Bou Salem (Tunisia). The disease progress curve (AUDPC) was used to screen this collection, and the effect of days to heading $(\mathrm{DH})$ and plant height $(\mathrm{PH})$ were evaluated in relation to TS resistance. No significant correlation of PH with AUDPC was found, yet a significant correlation $(r=0.212, p \leq 0.05)$ was established between DH and AUDPC scores, suggesting that DH may have an effect on TS development. Moreover, correlation between seedling and adult reactions was significant $(r=0.695, p \leq 0.001)$. Although susceptible accessions clustered separately from resistant accessions, the clustering was independent of the country of origin and the status of improvement of the wheat accessions. In total, $67 \%$ and $80 \%$ of resistant and moderately resistant accessions, respectively, were landraces, suggesting therefore the possible presence of novel sources of resistance to Ptr in some landraces, which can be used to establish a breeding program for resistance to tan spot disease.
\end{abstract}

Keywords: tan spot; durum wheat; landrace; diversity; plant height; days to heading; resistance

\section{Introduction:}

Durum wheat (Triticum turgidum L. subsp. durum) has a significant agricultural importance and represents the third most important cereal crop worldwide, accounting for $8 \%$ of the wheat planted area and provides $5 \%$ of the total wheat production worldwide [1,2]. It originated in the Fertile Crescent and spread west of the Mediterranean basin to North Africa 9000 years ago. It was also introduced to the latter region mainly from Egypt, Greece and Italy, hence, making it one of the secondary centers of diversification of durum wheat $[3,4]$. Most of the durum wheat is grown in the Mediterranean region $(75 \%$ of the world's durum wheat production) because of its adaptation to the environment and its end-use products such as semolina, pasta, couscous, and burghul [5,6]. In Tunisia, durum wheat is cultivated in over half a million hectares, representing $87 \%$ of the area dedicated to wheat production [7].

Climate change, abiotic and biotic stresses and the decreasing area for suitable farmland constitute considerable threats to wheat production. In addition, wheat production is threatened by the emergence of high-yielding elite cultivars grown in large areas that led to the loss of genetic diversity that are more vulnerable to newly emerging strains of pathogens [8-12]. The adoption and widespread of reduced or no-till practices in the 1970s 
led to the increased level of fungal primary inoculum in many wheat production areas, thus the establishment of stubble-borne destructive foliar diseases such as tan spot disease [13-15]. In Tunisia, tan spot has gained importance over the last few years on durum wheat [16]. Increased adoption of minimum, no till agronomic practices, and monoculture of limited durum wheat varieties led to disease outbreaks that often caused important yield losses. Tan spot caused by the necrotrophic fungus Pyrenophora tritici-repentis (Ptr) (anamoph: Drechslera tritici-repentis) infects both durum and bread wheat. The pathogen overwinters on wheat infested stubble as pseudothecia, which releases ascospores the following cropping season that are considered to be the primary source of inoculum infecting wheat seedlings $[17,18]$. Symptoms appear as tan-brown flecks that can expand into lens-shaped, tan lesions with a yellow halo [19]. Conidia produced in maturing lesions on leaves serve as secondary inoculum, leading therefore to the spread of the disease to the upper leaves and adjoint plants. Several studies discussed and confirmed the possible effect of agronomic traits such as plant height, days to heading and days to maturity on the severity of diseases such as Septoria tritici blotch (STB), spot blotch and tan spot. As a matter of fact, the flag leaves and glumes, important in grain filling, are infected with conidia earlier on short and early heading and early maturing plants than on tall and later heading and maturing plants [20-22]. Nevertheless, other studies reported the opposite conclusion or that these traits do not affect disease severity in any way [23-25].

Under favorable conditions for disease development, tan spot can cause up to $50 \%$ yield losses and reduce grain quality by the formation of red or pink smudge, particularly in durum wheat $[17,26-28]$. Several management strategies such as the use of non-host plants in the crop rotation, chemical control, and wheat variety genetics are available. However, one single strategy is not sufficient to control the disease. In Tunisia, tan spot management has basically relied on chemical control in conjunction with other diseases such as STB and yellow rust. However, the high pathogenic variability and high genome plasticity of $P$. tritici-repentis may limit the effectiveness of resistance due to the rapid and frequent emergence of new virulent strains [29-31]. An integrated control that includes cultivar mixtures, gene pyramiding and crop rotation represents the most effective and environmentally friendly alternatives providing control of tan spot [17,32-34]. Accordingly, the identification of wheat genotypes that have novel resistance genes and that yield well under a wide range of climatic conditions is crucial [35]. Despite that tan spot is a threat to durum wheat production worldwide, limited sources of resistance to Ptr have been identified so far, compared to common wheat.

Tunisia, situated on the Mediterranean coast of North Africa, is considered as one of the main secondary centers of diversification of durum wheat [4]. The earliest cultivated forms of wheat were essentially landraces that are heterogeneous and farmer-developed populations having a wide adaptation. These wheat landraces conceal a broad, diverse genetic base of cultivated wheat [36-39]. The increased prevalence of tan spot urged breeders to explore novel sources of resistance, particularly in landraces that represent an important group of genetic resources for the improvement of commercially valuable traits. Several studies using morphological, physiological and agronomic traits have shown that genetically diverse local germplasm well adapted to the environmental conditions can be considered as an important reservoir of useful genes for exploitation in wheat breeding programs [40-42]. Hence, screening durum wheat landraces for resistance to Ptr could represent an alternative source of resistance.

The objective of the present study was to look for potentially new sources of resistance to tan spot by screening a diverse collection of durum wheat germplasms that mostly included landraces. The responses of these accessions to tan spot were assessed in the field at seedling and adult plant growth stages to characterize the resistance to Ptr at seedling and adult-plant. This study also looks at correlations between disease development, plant height and days to heading. 


\section{Materials and Methods}

\subsection{Plant Materials}

A durum panel consisting of 113 accessions provided by USDA-Gene bank (Aberdeen, ID, USA), including accessions from 12 different Mediterranean countries (Algeria (2), Egypt (7), Greece (9), Israel (2), Italy (10), Jordan (7), Lebanon (1), Morocco (26), Portugal (15), Spain (14), Syria (2) and Turkey (18)) was tested for resistance to Ptr under field conditions. These materials were at different improvement statuses, including landraces (78), cultivars (12), breeding material (7) and uncertain improvement status (16) (Table S1, Figure 1).

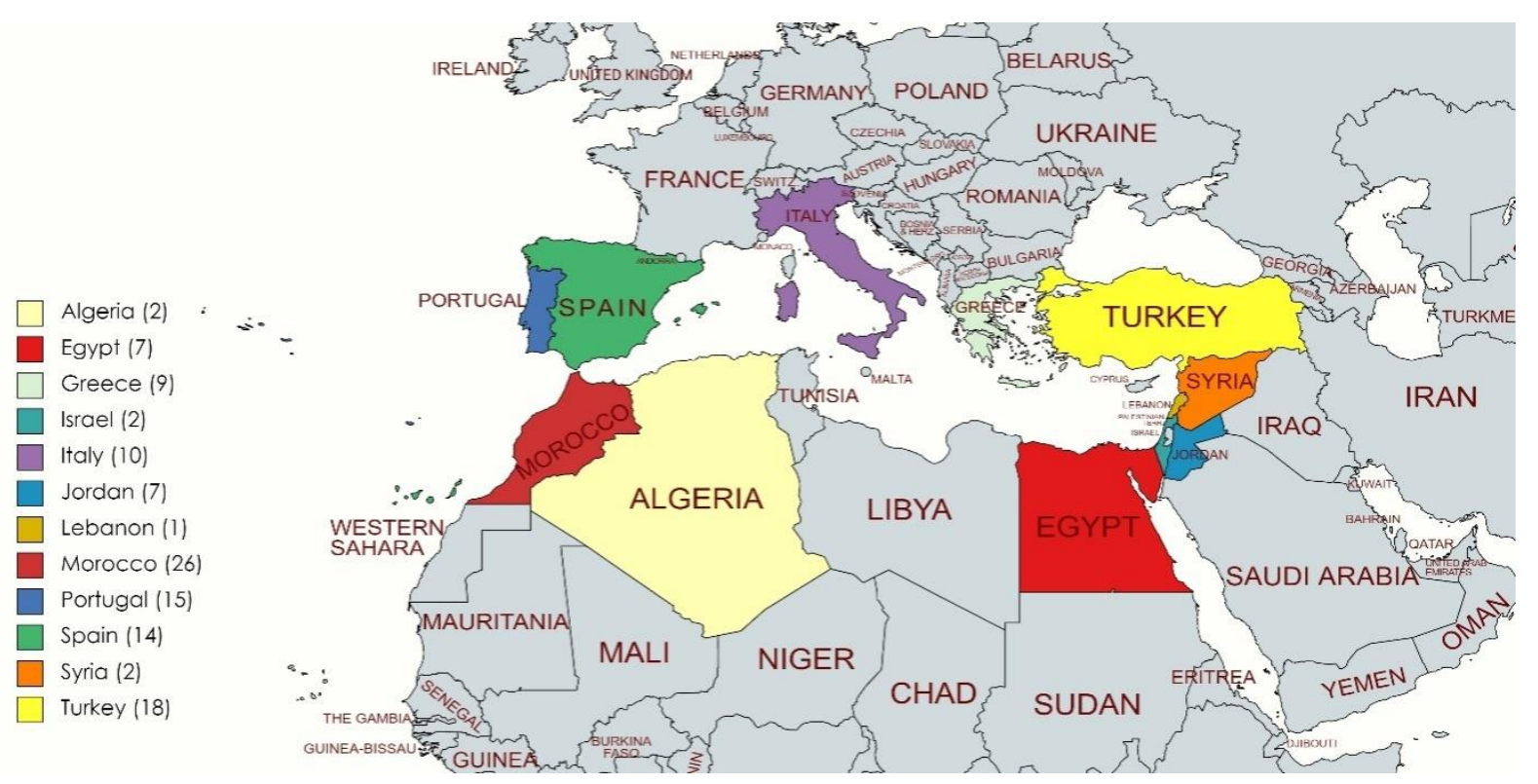

Figure 1. Geographical distribution of durum wheat accessions used in the present study.

\subsection{Experimental Design and Inoculation Method}

Durum wheat accessions were planted on 13 November, 2018, in a wheat-after-wheat production system, at the experimental station of the Septoria precision phenotyping platform of Tunisia based at INGC- Koudia research station, (Bou Salem, Governorate of Jendouba). This region is known to be a hot spot for tan spot disease where infection occurs annually. In fact, a recent study by Kamel and Cherif [16] showed that over $80 \%$ of tan spot incidence and severity were found in the region of Jendouba (Tunisia) in 2018 and that over a survey of 3 years, the atmospheric relative humidity was not a limiting factor for disease development and the temperatures recorded were favorable for tan spot development.

The experiment was conducted in an augmented design with unreplicated entries. These entries were sown in plots of two rows with $1 \mathrm{~m}$ length. Local checks, 'Nasr' and 'Salim', known for their susceptibility and resistance to tan spot disease, respectively, were also sown in two rows and replicated four times among blocks and the average of these replicates was used to classify the different accessions. The replicated checks were also used as a tool to verify the uniformity of the infection among and within plots. Spacing between plots and blocks was $50 \mathrm{~cm}$ and $1 \mathrm{~m}$, respectively. The middle of the block was planted with the susceptible variety 'Nasr', which served as a disease spreader.

In October, before sowing, straw from the previous cropping season was incorporated into the soil with a rotary harrow. The inoculum density was approximately $1 \mathrm{~kg} \mathrm{~m}^{-2}$. Additional inoculation was performed when the tested material reached the GS14 stage [43] by evenly spreading freshly cut infected wheat straw over the experimental plots and disease spreader rows, using susceptible cv, to ensure optimal disease development. The infected debris were obtained from the same experimental station of the previous cropping 
season, which was highly infected by the disease. Irrigation was applied in the evenings creating favorable conditions for disease infection and standard wheat agronomic practices were followed during the trial period.

\subsection{Agronomic Traits}

Plants were characterized by the following traits: Days to heading (recorded for all genotypes when approximately $50 \%$ of the plants in a plot had spikes fully emerged from the boot (GS 55) [43] and plant height (each plot was measured using a yardstick (in $\mathrm{cm}$ ) from the ground level to the tip of the spikes at the maturity stage).

\subsection{Disease Severity Rating}

The collection of 113 accessions, which mostly included Mediterranean durum wheat landraces, were evaluated for tan spot resistance under field conditions. The inoculated plants were evaluated for the severity of their reaction to $P$. tritici-repentis infection at GS30 [43] using a slightly modified 0-5 lesion rating scale [19], as outlined in Table 1. Scores equal to 5 indicated susceptibility, while those equal to 4 indicated a moderately susceptible reaction of the genotype. Scores equal to 3 indicated a moderately resistant reaction of the genotype, while those equal or less than 2 indicated resistance.

Table 1. Disease score ( $0-5$ scale) based on lesion appearance used to assess the severity of Pyrenophora tritici-repentis lesions.

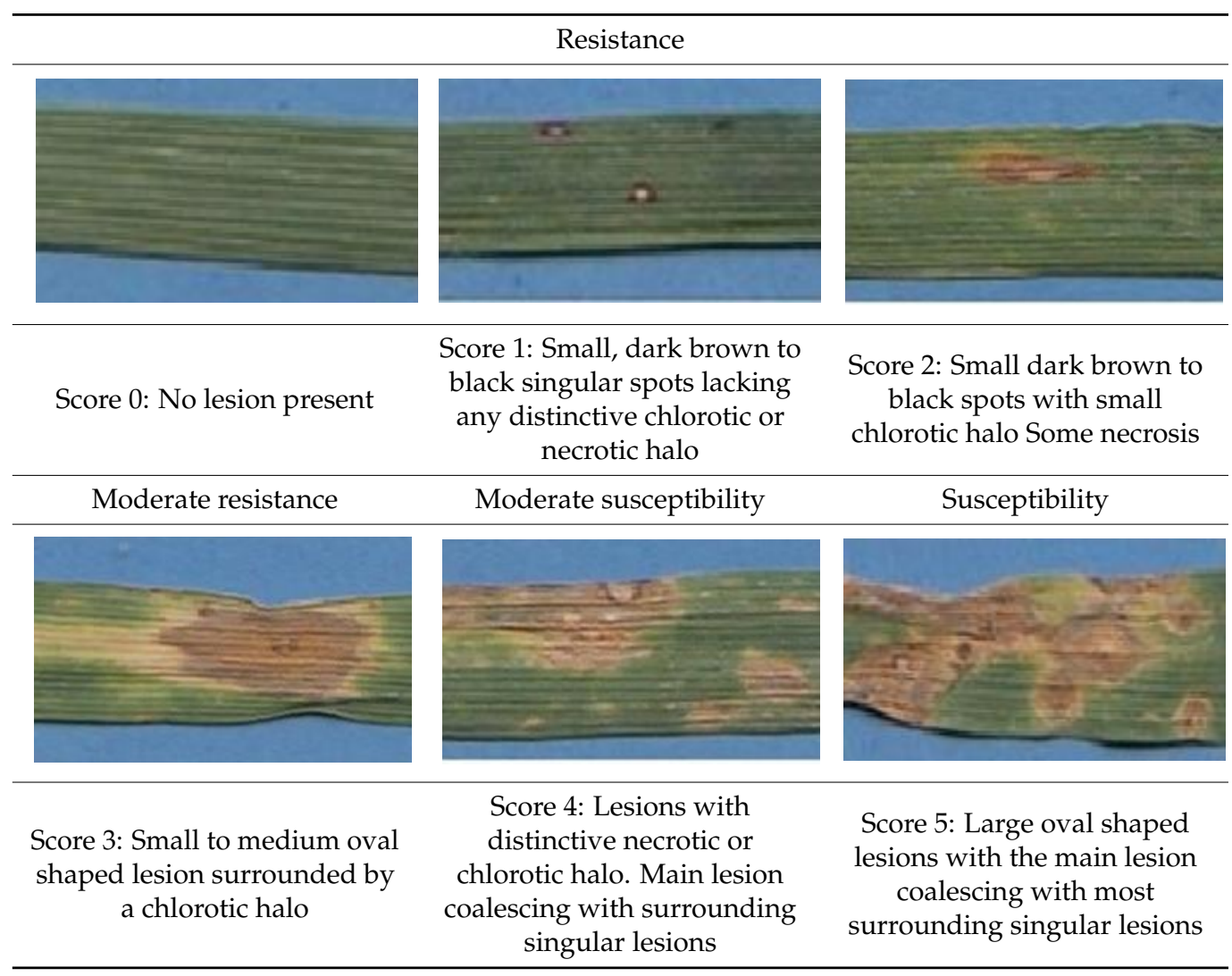

Resistance expressed at the seedling stage in growth chamber/greenhouse may or may not be expressed at the adult stage in the field. It was, therefore, highly important to compare seedling resistance with adult plant resistance under field conditions. Disease assessment was also carried out at three consecutive time points at GS55 [43] with a 7-day interval between each evaluation. Subsequently, tan spot progression was evaluated by measuring the incidence and severity based on the double-digit scale (00-99) [44] where the first digit indicates disease incidence on the infected plants, and the second digit refers 
to the severity of infection. The area under disease progress curve (AUDPC) was calculated according to the formula shown below [45]:

$$
A U D P C=\sum_{i=1}^{n-1} \frac{y_{i}+y_{i+1}}{2} \times\left(t_{i+1}-t_{i}\right)
$$

where:

$Y_{i}=$ disease severity at time $t_{i}$

$t_{(i+1)}-t_{i}=$ time interval (days) between two disease scores

$n=$ numbers of scoring events

\subsection{Statistical Analysis}

R software version 4.0.5 [46] was used for all data analysis. Principal Components Analysis (PCA) was performed using the 'prcomp' function from the R package 'MASS' [47]. The determination and visualization of the optimal number of clusters were performed using the 'fviz_nbclust' function from the R package 'factoextra' using the method «within cluster sums of squares» [48]. The 'clusGap' function from R package 'cluster' was used to calculate gap statistic based on number of clusters [49]. The 'kmeans' function from the $\mathrm{R}$ package 'stats' was used to perform k-means clustering with the optimal k [46]. Finally, the coefficient of correlation between variables was performed with the 'cor.test' function from the R package 'stats' [46].

\section{Results and Discussion}

\subsection{Reaction of Durum Wheat Accessions to Tan Spot}

All Mediterranean durum wheat accessions evaluated against tan spot responded differentially to Ptr under field conditions at both seedling and adult stages, exhibiting reactions that ranged from susceptible (S) to moderately susceptible (MS) and moderately resistant (MR) to resistant (R). As AUDPC is inversely proportional to the degree of resistance, accessions having low AUDPC are resistant while those with high AUDPC are susceptible (Table S1). Subsequently, the AUDPC scores of accessions were classified in comparison to the AUDPC of the resistant and susceptible checks implemented in the experimental design. The average AUDPC of the resistant and the susceptible checks ('Salim' and 'Nasr') were estimated as 492.901 and 721.605, respectively (Table S2). Therefore, resistant accessions (R) have an AUDPC that is ranged between 268.518 and 487.654 and between 497.530 and 598.765 for moderately resistant (MR) accessions. Accessions with AUDPC scores from 617.901 to 711.111 were considered moderately susceptible (MS), while those with AUDPC scores greater than 725.925 were considered susceptible (S).

\subsection{Comparison of Seedling and Adult Plant Resistance}

Tan spot infection was uniform among and within all inoculated plots. Disease symptoms are illustrated in Figure 2.

On average, $56 \%$ of the accessions were resistant (R), $27 \%$ moderately resistant (MR), $12 \%$ moderately susceptible (MS) and 5\% susceptible (S) under field conditions at the seedling stage whilst at the adult stage, $41,27,14$ and $18 \%$ were classified as R, MR, MS and S, respectively (Figure 3). Among the 46 accessions resistant at the adult stage, 31 (67\%) were landraces. In total, $80 \%$ of MR accessions were landraces. Table S1 shows the list of accessions, their country of origin, improvement status, plant height $(\mathrm{PH})$, days to heading $(\mathrm{DH})$ and disease scores at seedling and adult stages (AUDPC). 


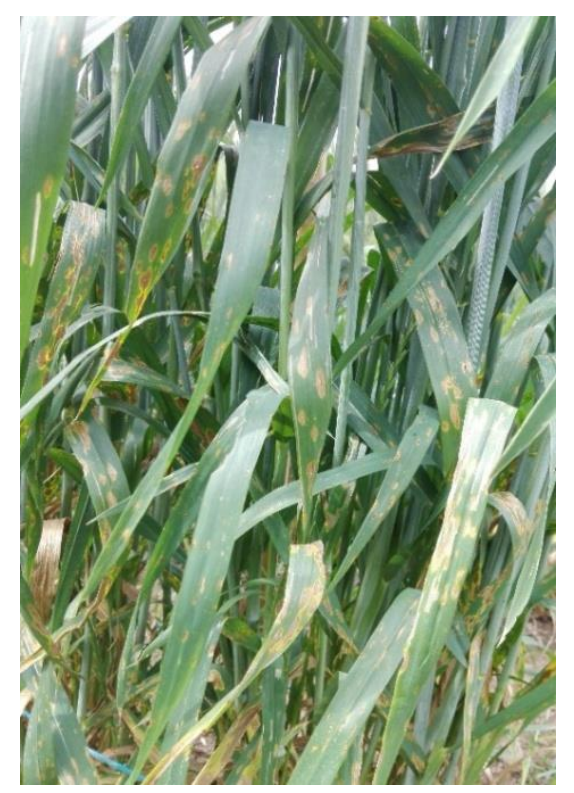

Figure 2. Typical tan spot symptoms in the field at the adult stage corresponding to GS55 at the Septoria Precision Phenotyping Platform (Experimental station of Koudia, Bou Salem, Tunisia).

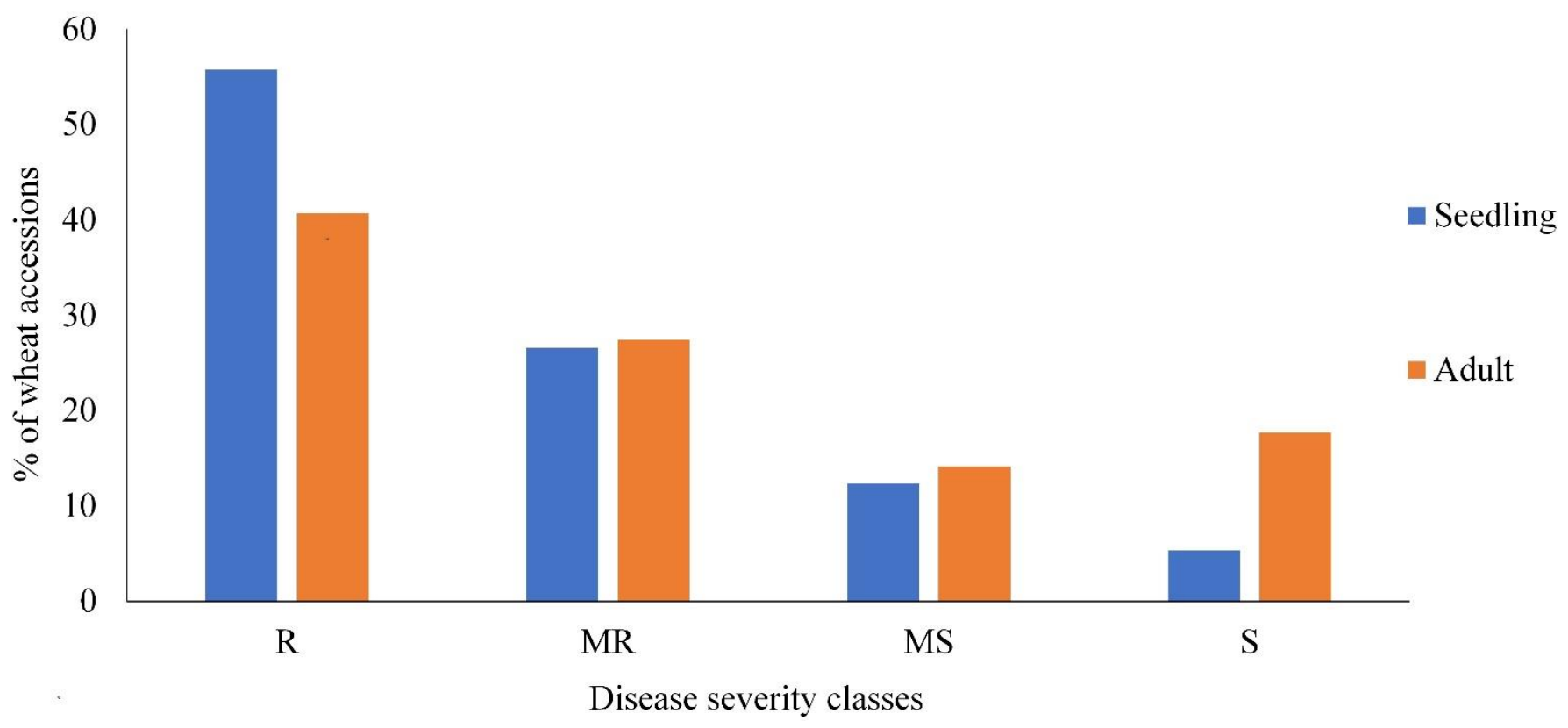

R: Resistant; MR: Moderately Resistant; MS: Moderately susceptible; S: Susceptible

Figure 3. Frequencies of resistance levels (\%) of the 113 durum wheat accessions to tan spot disease in the field at seedling and adult stages in the 2018-2019 cropping season.

Among the 63 accessions that were $\mathrm{R}$ at the seedling stage, 40 showed similar resistance levels at the adult stage, then 17 were MR, 5 were MS and one accession was classified as $S$ at the adult stage. Among 30 accessions having an MR reaction at the seedling stage, 12 remained MR, 4 were MS, 6 were $R$ and 8 were classified as $S$ at the adult stage. Overall, $63 \%$ and $40 \%$ of accessions maintained the same level of resistance (R-MR) at both seedling and adult stages. Among 14 accessions having an MS reaction at the seedling stage, 5 remained MS, 2 were MR, and 7 were $S$ at the adult stage. Among 6 accessions of $S$ type at the seedling stage, two were MS and four were $S$ at the adult stage. 
At the seedling stage, the collection from Spain had the largest number of resistant accessions (12), followed by those from Turkey (10). The accessions from Greece and Portugal had eight resistant accessions at seedling stages, followed by six accessions from Egypt and Italy (Figure 4). The same trend was observed at the adult stage with accessions from Spain having the largest number of resistant accessions (9), followed by Greece (8), Egypt (5), Portugal (5) and Turkey (5) (Figure 5). The accession from Lebanon showed MS and $S$ reactions at seedling and adult stages, respectively (Figures 4 and 5) and thus have no effective resistance at both stages. Durum wheat from Morocco had the greatest number of susceptible accessions at both seedling and adult stages with three and five genotypes, respectively (Figures 4 and 5).

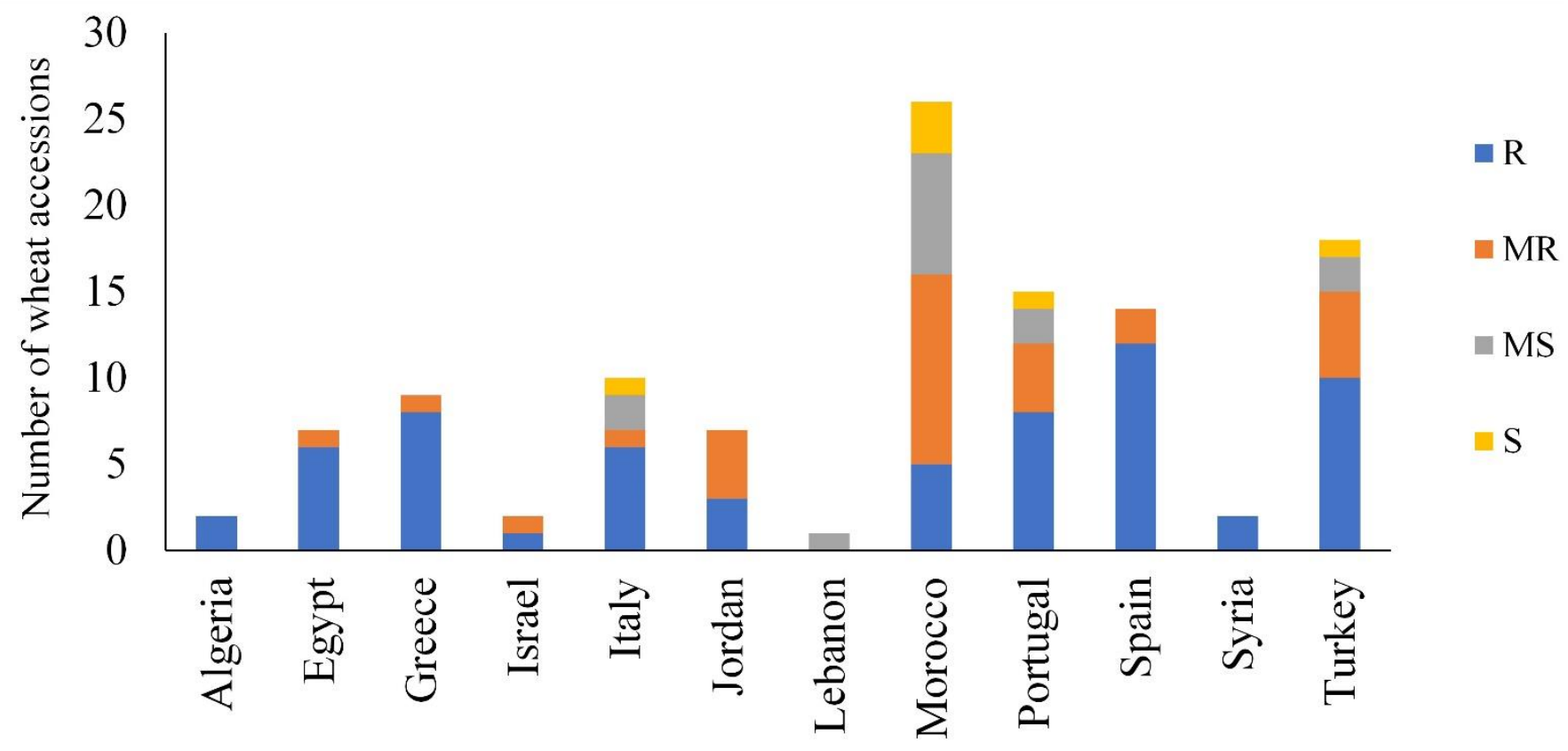

\section{Country of origin}

\section{R: Resistant; MR: Moderately resistant: MS; Moderately susceptible; S: Susceptible}

Figure 4. Resistance levels of 113 durum wheat accession's reactions to tan spot disease in-field at the seedling stage among countries of origin in the 2018-2019 cropping season.

At the seedling stage, $82 \%$ of durum wheat landraces had a good level of resistance (R-MR). While at the adult stage, $71 \%$ maintained their level of resistance, suggesting that these landraces may be an important source of useful genes for Ptr resistance as previously reported in accessions of spring wheat landraces (Table S1) $[38,39]$.

Correlation between seedling and adult reactions was significant (Pearson's correlation $r=0.695, p$-value $\leq 0.001$ ). Positive correlation has been reported between assessments of resistance at the seedling stage and of adult plants in the field in several studies. Greenhouse evaluation based on lesion length and field assessments of the AUDPC for tan spot resistance in Oklahoma (USA) were found to be significantly correlated [50]. Likewise, a significant correlation was observed between field disease ratings and greenhouse disease ratings in North Dakota (USA) even though the correlation coefficient ranged from $r=0.29$ to 0.50 depending on the observer and the type of disease severity rating [23]. Similarly, in a study of the resistance to tan spot disease in winter wheat cultivars at different growth stages, a significant correlation $(r=0.86)$ was reported for greenhouse and field tan spot reactions in winter wheat [51]. Therefore, screening for tan spot at the seedling stage is often preferred to allow the most susceptible materials to be discarded before confirmation of field resistance. Although significant correlation was often established between seedling 
and adult stages' reaction types [50,52], there were some inconsistencies in infection type between different growth stages [53]. The difference between seedling and adult reactions is likely due to the presence of APR factors in some genotypes that confer incomplete or partial resistance in the field [54]. Hence, adult plant resistance (APR) may serve as an effective tool in the search of broad-spectrum resistance as it is mostly polygenic and provides more resistance than the seedling. In a study of relationship of seedling and adult plant resistance to Ptr, most of the cultivars were found to have slightly higher levels of susceptibility at the adult stage under field conditions than at the seedling stage in greenhouse conditions, even though there was a similar trend between the two resistance levels across cultivars [52]. This was attributed to the interaction of different $P t r$ isolates; the amount of inoculum that resulted from wheat monoculturing over several years under field conditions was higher in comparison to the growth chamber conditions where accessions were tested using a single monoconidial Ptr isolate [52].

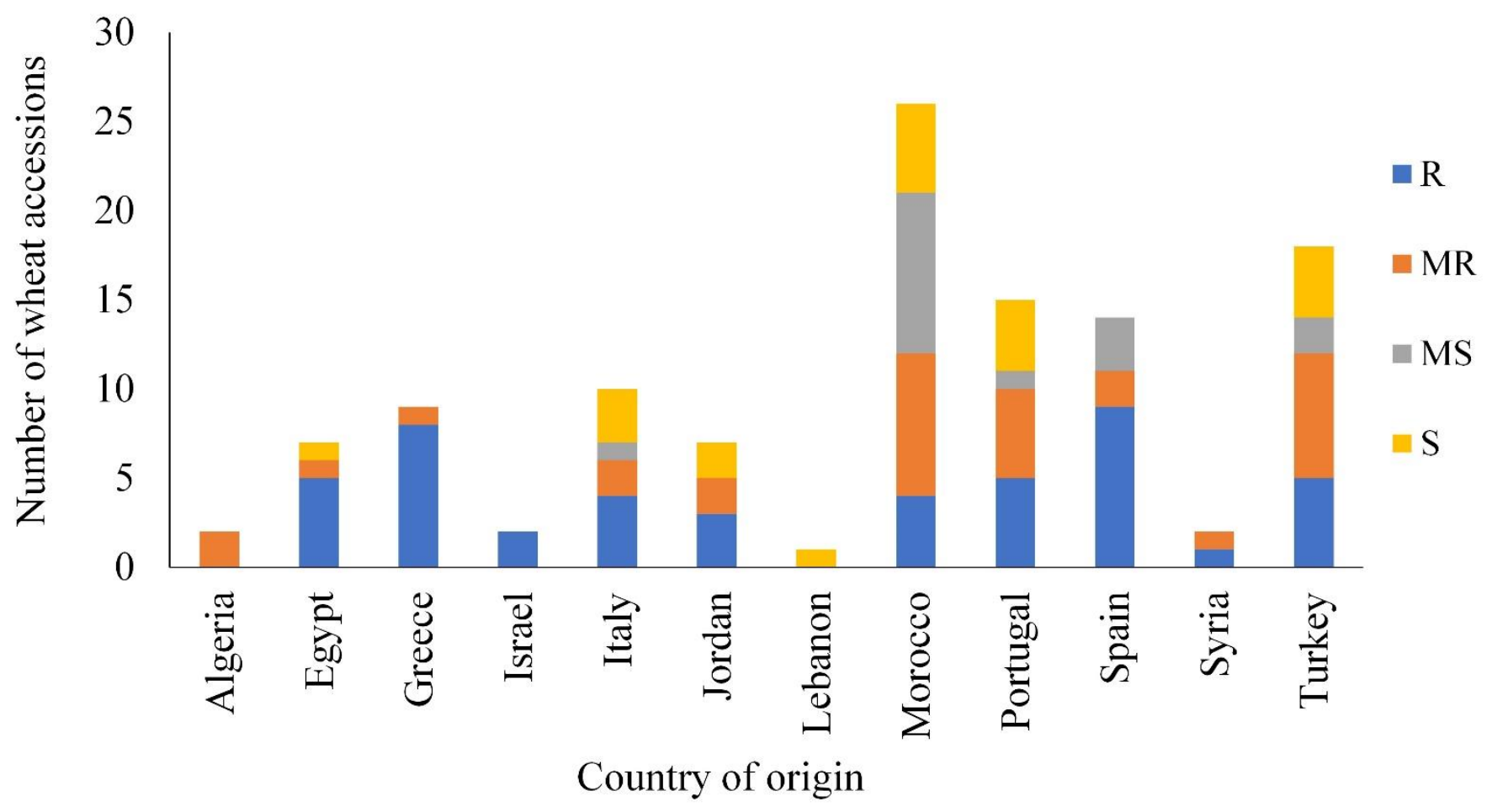

\section{R: Resistant; MR: Moderately resistant; MS: Moderately susceptible; S: Susceptible}

Figure 5. Resistance levels of 113 durum wheat accession's reactions to tan spot disease in-field at the adult stage among countries of origin in the 2018-2019 cropping season.

Moreover, Ptr-Wheat interaction follows an inverse gene-for-gene model where susceptibility results from the unique interaction between Necrotrophic effectors (NEs) termed Ptr ToxA, Ptr ToxB and Ptr ToxC, and specific receptors in the host termed Tsn1, Tsc2, and Tsc1, respectively, while the lack of NE recognition by the host leads to resistance [13,34]. The inheritance of resistance to tan spot is known to be both qualitative and quantitative [13,18,39,55-59]. To date, nine major Tsr genes (Tsrl, Tsr2, Tsr3, Tsr4, Tsr5, Tsr6, Tsr7, TsrHar and TsrAri) have been identified [60-66]. Numerous studies have reported quantitative resistance to Ptr that is effective against multiple races of the pathogen (non-racespecific resistance) $[13,18]$. In the case of Ptr, breeding strategies include the elimination of susceptibility genes, or the introgression of broad-spectrum resistance genes [13]. However, the removal of these gene can result in undesirable effects such as susceptibility to other pathogens as well as the loss of genetic diversity and useful genes that may be affecting other important traits. Many studies suggested the involvement of multiple NE-host 
interaction(s), which may depend on plant growth stages [52,67-69]. In a recent study, Kokhmetova et al. [70] attributed resistance to tan spot to the known toxin insensitivity genes with major effects as well as broad-spectrum and race-non-specific genes, which have minor effects.

Recent studies conducted on Ptr in Tunisia by Laribi et al. [71,72], Kamel and Cherif [16] and Kamel et al. [73] revealed the presence of six Ptr races $(2,4,5,6,7,8)$ as well as 'atypical' isolates that were able to cause necrosis on the differential line 'Glenlea' but lacked the expected ToxA gene, suggesting therefore the involvement of additional NEs in the $\mathrm{Ptr} /$ wheat interaction in the North Western region (NWR) of Tunisia where the experiment was conducted. The predominant races in the latter region were races 5, 7 and 'atypical' isolates, while Ptr ToxB was found to be predominant. A recent study by Laribi et al. [71] showed that the Ptr population from (NWR) was genetically highly diverse. Hence, screening for resistance in the latter region may provide information not only on resistance to the prevalent races in Tunisia but also on broad-spectrum resistance to multiple NEs. Adult plant resistance (APR) is often preferred over seedling resistance as it has the potential to provide non-race specific resistance to TS [13]. Therefore, the identification of accessions with non-race specific resistance to Ptr can be a major step towards the development of lines that are resistant to Ptr. The resistance response of the tested accessions in this study may be associated with the diversity of Ptr in Tunisia similarly to the study of Dinglasan et al. [68] where they hypothesized that the prevalence of diverse Ptr populations from Russia, India, Pakistan and India was a main factor influencing wheat selection pressure. In the latter study, a number of accessions carrying all-stage resistance genes (ASR) mainly originated from Russia and India, while those with APR were from Pakistan and India. Similarly, Liu et al. [74] found that the number of resistant lines decreased when inoculated with more than one isolate. Hence, screening the 113 accessions against multiple races/isolates in fact increased the chances of these accessions having sources of durable resistance. Disease response was also found to differ between ToxA insensitive and sensitive accessions at seedling but not at adult-plant stages suggesting that other genetic factors or interactions contribute to disease response at the adult-plant stage [68].

Adult plant resistance (APR) occurs in mature plants and provides partial resistance. APR is a quantitative form of disease resistance that is considered more durable and has been deployed effectively in other host pathosystems such as leaf rust and stripe rust. For instance, some APR genes have been proven to provide resistance to all isolates of a pathogen species (broad spectrum) and/or resistance to multiple pathogen species, such as, the $L r 67$ and $L r 34$ genes, respectively [75-77]. As APR genes are mostly race non-specific, they most likely provide similar levels of resistance to different $P t r$ races. It is most often desired by wheat breeders as it allows effective selection for resistance to Ptr, whereas seedling resistance, even though time consuming for breeders, is important as it reduces primary inoculum spread.

As established by other researchers, durable resistance gene pyramiding represents an alternative to ensure an effective resistance against fungal pathogens for a longer time in a conducive environment favorable to disease development $[33,34]$. This requires the availability of resistant genetic resources and a better understanding of the host-pathogen interaction. The identification of genetically diverse lines with respect to tan spot resistance is of extreme relevance to select parents for breeding programs so as to pyramid genes from different resistant resources into a single genotype. In fact, it has been widely agreed that partial resistances to fungal pathogens are effective and durable [78-80]. The genetic complexity of the resistance at multiple scales is a guarantee to ensure a successful and long-lasting resistance, unlike resistance based on a single gene, which can be effective in the short term [57]. The majority of genetic studies have observed that resistance to tan spot is controlled by multiple major genes and the rare interaction between different genes imply that all genes need to be incorporated to develop durable and effective resistant cultivars [55-59]. 
Many accessions in this study displayed an immune response or a high level of resistance under field conditions at both seedling and adult stages (40 and 14 accessions maintained a resistant and moderate response), probably as a result of synergy between APR genes or between APR and seedling resistance genes. Therefore, these accessions may provide all-stage resistance genes (ASR) functional at all stages of plant development. Hence, they can be deployed as potential sources for improvement of $\mathrm{Ptr}$ resistance. The results of this study also highlight the potential of durum wheat landraces for Ptr resistance and the importance of gene pyramiding to provide sustainable resistance. The transfer of these probable additional novel genes into currently commercialized cultivars would provide a more effective and durable resistance.

\subsection{Correlation of Tan Spot Infection with Plant Height and Days to Heading}

In addition to the disease response, we also recorded the plant height $(\mathrm{PH})$ and days to heading (DH) in order to identify any association to tan spot infection. We observed a significant variation within the collection in relation to these traits, as indicated in Table S1. $\mathrm{PH}$ ranged from 85 to $165 \mathrm{~cm}$ and from 138 to 164 days for $\mathrm{DH}$, respectively. PH for local checks 'Nasr' and 'Salim' were 100 and $95 \mathrm{~cm}$, respectively. The shortest accession was $85 \mathrm{~cm}$ for PI numbers 371822, 404588 and 517188 while the tallest height was $165 \mathrm{~cm}$ for PI 487293. DH for local checks 'Nasr' and 'Salim' were 132 and 134 days, respectively. The greatest DH, among the 113 accessions, was 164 days for PI numbers 525387, 341453 and 341612 while the lowest DH was 138 for PI 517188. To further understand the effect of PH and DH on tan spot infection, a principal component analysis (PCA) was conducted $[81,82]$ using PH, DH and AUDPC as parameters. Results showed two dimensions of PCA explaining $79.7 \%$ of data variance (Figure 6 ). The first dimension accounted for $46.5 \%$ of the variances while the second dimension accounted for $33.2 \%$ of variances.

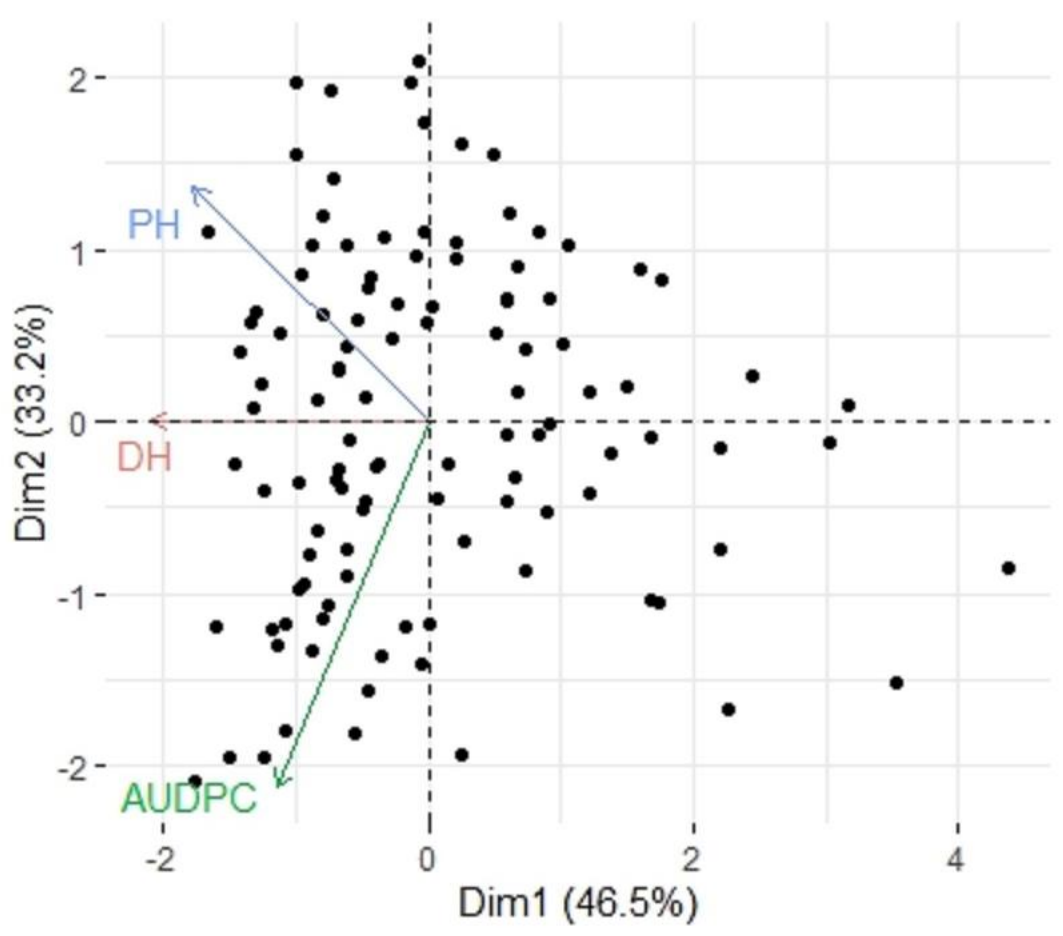

Figure 6. Principal component analysis (PCA) representing the contribution of three factors: plant height $(\mathrm{PH})$, days to heading $(\mathrm{DH})$ and AUDPC scores in 113 accessions.

In an attempt to classify the different accessions, two clusters were conducted using the R function "K-means". The first cluster (Figure 7A) included all 113 accessions and allowed the classification of wheat accessions into four different clusters. The first cluster (red) consisted of 37 accessions. Cluster 2 (green) contained 11 accessions. Cluster 3 
(blue), which is the largest cluster, contained 41 accessions. Finally, cluster 4 (purple) consisted of 24 accessions. Among 78 landraces, 24, 8, 30 and 16 belonged to clusters 1, 2, 3 and 4, respectively. Among 16 accessions with uncertain improvement status, 6 , 8 and 2 belonged to clusters 1, 3 and 4, respectively. Among seven breeding lines; one belonged to cluster 1, two belonged to cluster 2, one belonged to cluster 3 and three to cluster 4 . Among 12 cultivars, six belonged to cluster 1 , one belonged to both clusters 2 and 3 and three belonged to cluster 4 (Figure 7A, Table S1). The second cluster (Figure 7B) included 66 accessions (46 R and $20 \mathrm{~S}$ ) and allowed the classification of wheat accessions into four different clusters. Results showed two dimensions explaining $77.9 \%$ of data variance (Figure 7B). The first dimension accounted for $43.4 \%$ of the variances, while the second dimension accounted for $34.5 \%$ of variances. The first cluster (red) consisted of six accessions. Cluster 2 (green), which is the largest cluster, contained 23 accessions. Cluster 3 (blue) contained 20 accessions. Finally, cluster 4 (purple) consisted of 17 accessions. Clusters 1, 2 and 4 included all resistant accessions while susceptible accessions clustered separately in cluster 3 (Figure 7B). PH and DH ranged from 85 to $150 \mathrm{~cm}$ and from 138 to 164 days, respectively, for resistant accessions (Clusters 1,2 and 4) and from 120 to $150 \mathrm{~cm}$ and from 152 to 164 days, respectively, for susceptible accessions (Cluster 3).

The correlation between PH and AUDPC was $r=0.004(p=0.97>0.05)$, while the correlation between DH and AUDPC was $r=0.212(p=0.02 \leq 0.05)$. Thus, no consistent relationship between $\mathrm{PH}$ and AUDPC was found. Conversely, there is an association between DH and AUDPC. Likewise, in a study of heritability of resistance to tan spot in durum wheat and its association with other agronomic traits in North Dakota (USA), no significant correlation between plant height and the measurements of disease severity were reported [23]. In addition, in a recent study of tan spot resistance in a hexaploid wheat collection from Kazakhstan, correlation of PH with AUDPC scores was not found to be significant, further suggesting that PH does not significantly affect tan spot resistance [70]. Contrarily to our results, the latter study suggested no significant effect of DH on TS resistance. Similarly, in a study of tan spot resistance in the bread wheat variety Ernie, no significant correlations were detected between tan spot severity with either DH or $\mathrm{PH}$ [83]. However, many other studies reported a negative correlation between DH or $\mathrm{PH}$ with disease resistance; indeed, in a recent study of resistance of 372 European wheat varieties to tan spot disease in Germany, a highly significant negative correlation of tan spot infection with $\mathrm{PH}$ and a moderate negative correlation with $\mathrm{DH}$ were reported, indicating that plant height and late heading might be potential tan spot disease escape traits, therefore, indicating a role of plant height in disease expression [84]. In another study that characterized 358 European winter wheat cultivars and 14 spring wheat cultivars for their resistance to tan spot in Germany, the authors showed that shorter plants showed a tendency to be more susceptible while no significant correlation between Ptr resistance and DH was established [85]. The different outcome of these studies may be partially explained by the use of different germplasm and the conduction of these experiments in different environments. Similar contradictory conclusions have been reported in other diseases such as Fusarium head blight (FHB), Septoria nodorum blotch (SNB), and Septoria tritici blotch (STB) [86-88]. For instance, studies based on the relationship between leaf spot disease severity of wheat and $\mathrm{PH}$ and $\mathrm{DH}$ have shown negative associations for SNB and STB diseases in wheat $[21,89,90]$. Conversely, in a study that investigated the relationships between plant stature, maturity class, and susceptibility to STB, a low correlation was found between plant height and STB severity, suggesting that there is probably no linkage between shortness and susceptibility [91]. 


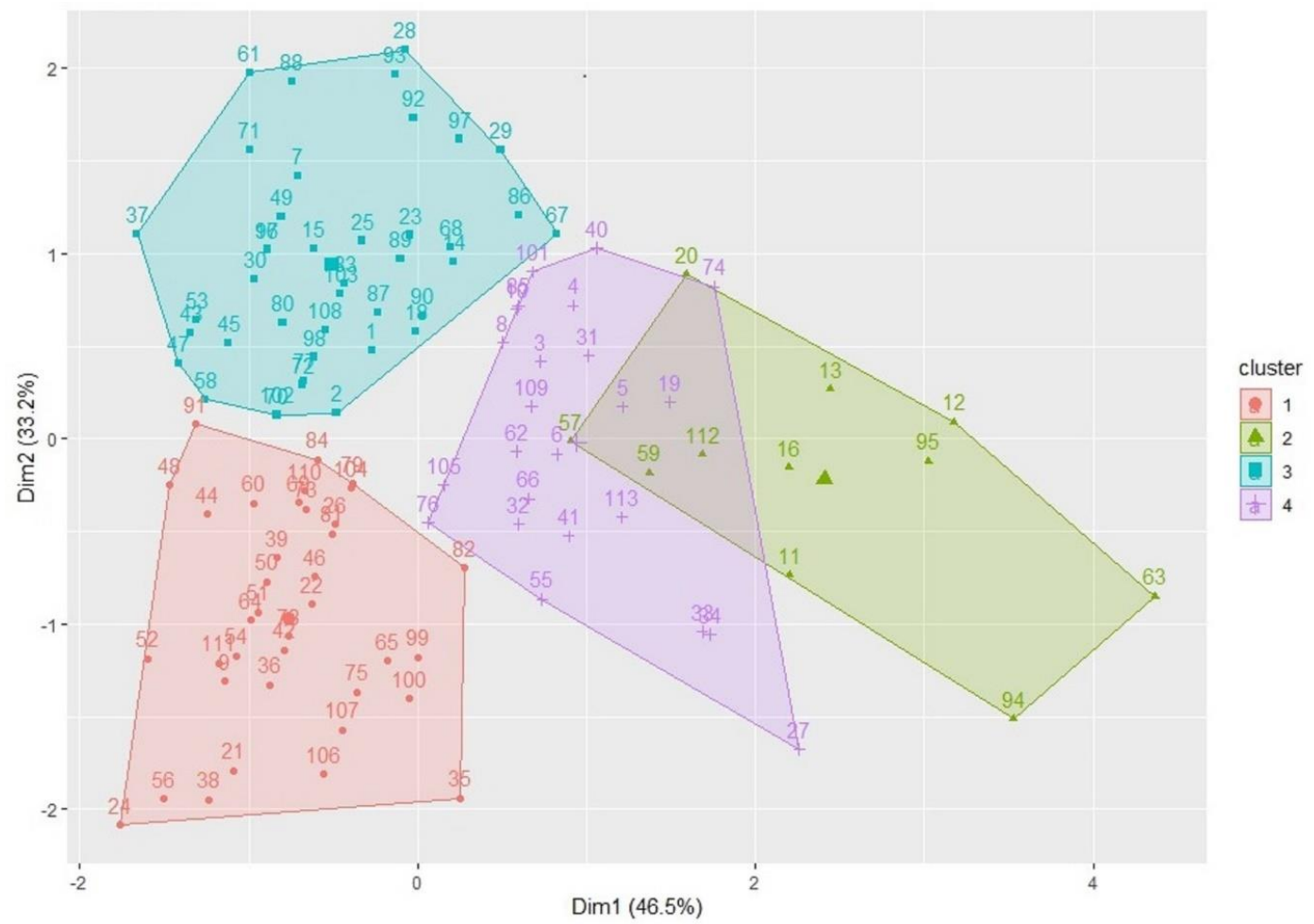

(A)

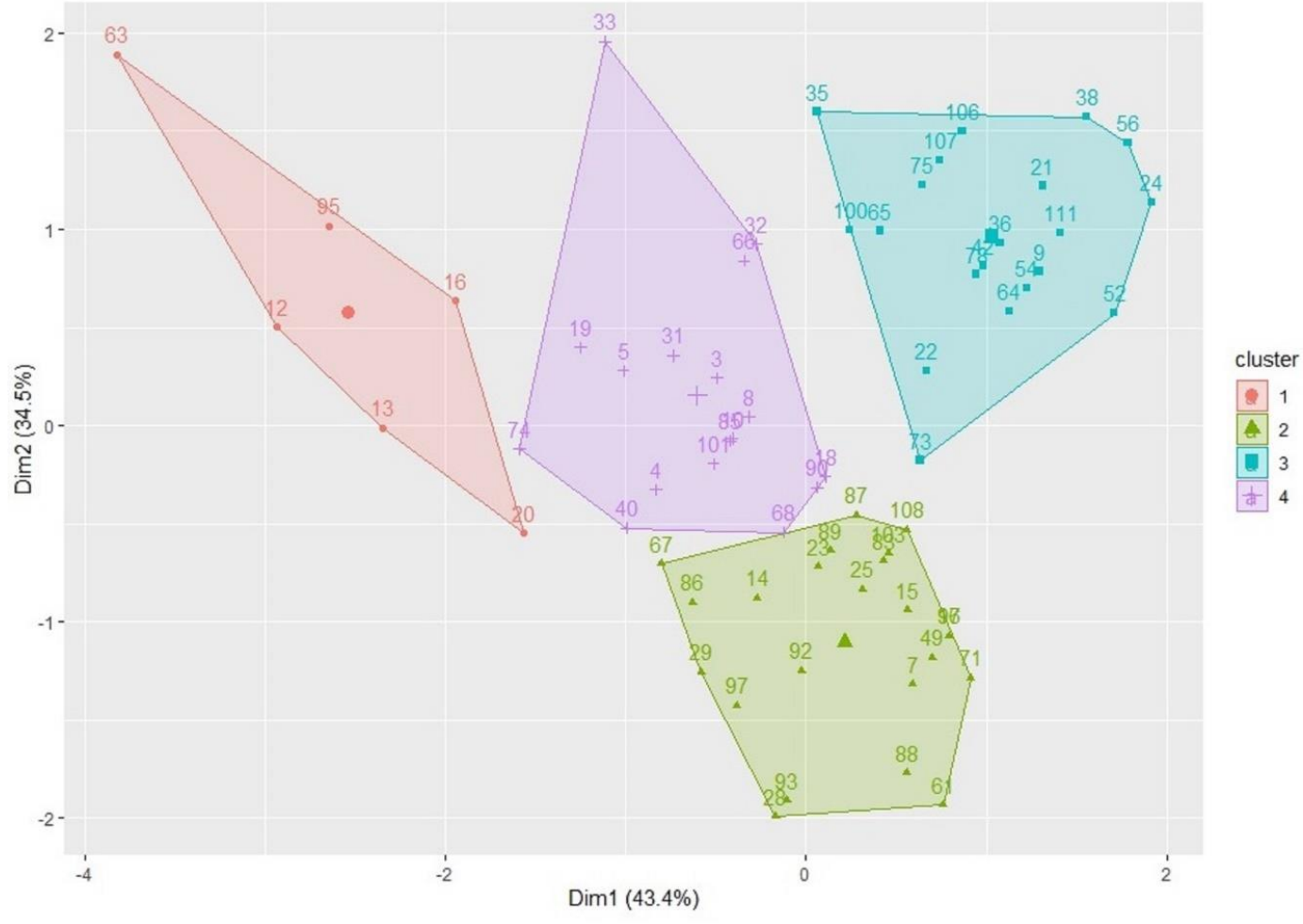

(B)

Figure 7. (A) Clustering of 113 wheat genotypes representing the contribution of 3 factors: Plant height (PH), days to heading (DH) and the area under disease progression curve (AUDPC); (B) clustering of 66 wheat genotypes (46 R and $20 \mathrm{~S}$ ) representing the contribution of 3 factors: plant height $(\mathrm{PH})$, days to heading $(\mathrm{DH})$ and the area under disease progression curve (AUDPC). 


\section{Conclusions}

In this study, field evaluations for tan spot resistance were conducted on a panel of 113 durum wheat accessions. The collection showed vast phenotypic diversity. We found that resistance and susceptibility reactions varied within and among countries and between seedling and adult stages. Our results showed no significant correlation between PH and AUDPC scores, whereas a significant correlation between DH and AUDPC was found, indicating that this trait may have an effect on disease resistance or susceptibility. Highly significant correlation between seedling and adult reactions was observed $(\mathrm{r}=0.695$, $p$-value $\leq 0.001)$, suggesting that screening accessions at the adult stage only or at the seedling stage can be sufficient for evaluating disease resistance. In this study, among 113 accessions, 40 and 14 accessions maintained resistant and moderately resistant reactions to tan spot disease at both seedling and adult stages under Tunisian field conditions, respectively, indicating most likely the presence of complete resistance. More in-depth research is required, as the latter accessions may harbor valuable all-stage resistance genes (ASR)/QTLs, hence, providing high levels of resistance to Ptr at all development stages that can be used in breeding programs. In addition to the importance of gene pyramiding to provide sustainable resistance, our results also emphasize the potential of durum wheat landraces as a new genetic solution to tan spot in Tunisia.

Supplementary Materials: The following are available online at https:/ / www.mdpi.com/article/10 .3390 /agriculture11111148/s1. Table S1: The list of accessions, their country origin, improvement status, plant height $(\mathrm{PH})$, Days to heading $(\mathrm{DH})$ and disease scores at seedling stage and adult stage (AUDPC). Table S2: The area under disease progress curve (AUDPC) of checks implemented in the experimental design.

Author Contributions: Conceptualization, M.L., A.H.Y. and S.B.M.; investigation, M.L.; writingoriginal draft preparation, M.L.; review and editing, M.L., S.B.M., A.H.Y., M.F. and K.S. All authors have read and agreed to the published version of the manuscript.

Funding: This work was supported by the CRP Wheat Septoria Precision Phenotyping PlatformTunisia (CIMMYT/IRESA).

Institutional Review Board Statement: Not applicable.

Informed Consent Statement: Not applicable.

Data Availability Statement: The data presented in this study are available within the article.

Acknowledgments: The authors would like to thank Harold Bockelman (USDA-ARS Aberdeen, ID, USA) for providing seeds and Hajer Kouki and Slim Arfaoui (INGC) for their field technical support.

Conflicts of Interest: The authors confirm that there is no conflict of interest to declare.

\section{References}

1. Fayaz, F.; Aghaee Sarbarzeh, M.; Talebi, R.; Azadi, A. Genetic Diversity and Molecular Characterization of Iranian Durum Wheat Landraces (Triticum turgidum durum (Desf.) Husn.) Using DArT Markers. Biochem Genet. 2019, 57, 98-116. [CrossRef]

2. International Grains Council [IGC]. World Grain Statistics 2016. 2020. Available online: https://www.igc.int/en/subscriptions/ subscription.aspx (accessed on 21 May 2020).

3. Feldman, M. Origin of cultivated wheat. In The World Wheat Book: A History of Wheat Breeding; Bonjean, A.P., Angus, W.J., Eds.; Lavoisier: Paris, France, 2001; pp. 3-56.

4. Harlan, J.R. Agricultural Origins: Centers and Non centers. Science 1971, 174, 468-474. [CrossRef] [PubMed]

5. Bonjean, A.P.; Angus, W.J.; van Ginkel, M. The World Wheat Book: A History of Wheat Breeding; Lavoisier: Paris, France, 2016; Volume 3.

6. Kabbaj, H.; Sall, A.T.; Al-Abdallat, A.; Geleta, M.; Amri, A.; Filali-Maltouf, A.; Belkadi, B.; Ortiz, R.; Bassi, F.M. Genetic Diversity within a Global Panel of Durum Wheat (Triticum durum) Landraces and Modern Germplasm Reveals the History of Alleles Exchange. Front. Plant. Sci. 2017, 8, 1277. [CrossRef]

7. USDA. Tunisia: Grain and Feed Annual; USDA Foreign Agricultural Service: Washington, DC, USA, 2019.

8. Chakraborty, S.; Tiedemann, A.V.; Teng, P.S. Climate Change: Potential Impact on Plant Diseases. Environ. Pollut. 2000, 108, 317-326. [CrossRef] 
9. Marzario, S.; Logozzo, G.; David, J.; Zeuli, P.; Gioia, T. Molecular Genotyping (SSR) and Agronomic Phenotyping for Utilization of Durum Wheat (Triticum durum Desf.) Ex Situ Collection from Southern Italy: A Combined Approach Including Pedigreed Varieties. Genes 2018, 9, 465. [CrossRef]

10. Newton, A.C.; Johnson, S.N.; Gregory, P.J. Implications of Climate Change for Diseases, Crop Yields and Food Security. Euphytica 2011, 179, 3-18. [CrossRef]

11. Ortiz, R.; Sayre, K.D.; Govaerts, B.; Gupta, R.; Subbarao, G.V.; Ban, T.; Hodson, D.; Dixon, J.M.; Iván Ortiz-Monasterio, J.; Reynolds, M. Climate Change: Can Wheat Beat the Heat? Agric. Ecosys. Environ. 2008, 126, 46-58. [CrossRef]

12. Soriano, J.M.; Villegas, D.; Sorrells, M.E.; Royo, C. Durum Wheat Landraces from East and West Regions of the Mediterranean Basin Are Genetically Distinct for Yield Components and Phenology. Front. Plant. Sci. 2018, 9, 80. [CrossRef] [PubMed]

13. Faris, J.D.; Liu, Z.; Xu, S.S. Genetics of Tan Spot Resistance in Wheat. Theor. Appl. Genet. 2013, 126, 2197-2217. [PubMed]

14. Hosford, R.M. Tan spot: Developing knowledge 1902-1981, virulent races and wheat differentials, methodology, rating systems, other leaf diseases, literature. In Proceedings of the Tan Spot of Wheat and Related Disease Workshop, Fargo, North Dakota, 14-15 July 1981; pp. 1-20.

15. Rees, R.G.; Platz, G.J. Tan spot and its control: Some Australian experiences. In Advances Tan Spot Research; ND Agricultural Experiment Station: Fargo, North Dakota, 1992.

16. Kamel, S.; Cherif, M. Tan spot of wheat in Northern Tunisia: Distribution, prevalence, incidence and severity. Cereal Res. Commun. 2021, 49, 1-12. [CrossRef]

17. De Wolf, E.D.; Effertz, R.J.; Ali, S.; Francl, L.J. Vistas of tan spot research. Can. J. Plant. Pathol. 1998, 20, 349-370.

18. Singh, P.K.; Duveiller, E.; Singh, R.P. Resistance breeding for tan spot (Pyrenophora tritici-repentis) of wheat. In Disease Resistance in Wheat; Sharma, I., Ed.; CABI: Wallingford, UK, 2012; pp. 136-150.

19. Lamari, L.; Bernier, C.C. Evaluation of Wheat Lines and Cultivars to Tan Spot [Pyrenophora tritici-repentis] Based on Lesion Type. Can. J. Plant. Pathol. 1989, 11, 49-56. [CrossRef]

20. Eyal, Z. Integrated control of Septoria diseases of wheat. Plant. Dis. 1981, 65, 763-768. [CrossRef]

21. Scott, P.R.; Benedikz, P.W.; Cox, C.J. A Genetic Study of the Relationship between Height, Time of Ear Emergence and Resistance to Septoria Nodorum in Wheat. Plant. Pathol. 1982, 31, 45-60. [CrossRef]

22. Fernandez, M.R.; Clarke, J.M.; DePauw, R.M. The Effect of Plant Height on Tan Spot on Durum Wheat in Southern Saskatchewan. Crop. Sci. 2002, 42, 159-164. [CrossRef]

23. Elias, E.; Cantrell, R.G.; Hosford, R.M. Heritability of Resistance to Tan Spot in Durum Wheat and Its Association with Other Agronomic Traits. Crop. Sci. 1989, 29, 299. [CrossRef]

24. Joshi, A.K.; Chand, R.; Arun, B. Relationship of plant height and days to maturity with resistance to spot blotch in wheat. Euphytica 2002, 123, 221-228.

25. Simon, M.R.; Perelló, A.E.; Cordo, C.A.; Larrán, S.; van der Putten, P.E.; Struik, P.C. Association between Septoria tritici blotch, plant height, and heading date in wheat. Agron. J. 2005, 97, 1072-1081. [CrossRef]

26. Fernandez, M.R.; DePauw, R.M.; Clarke, J.M.; Fox, S.L. Discoloration of Wheat Kernels by Pyrenophora tritici-repentis. Can. J. Plant. Pathol. 1998, 20, 380-383. [CrossRef]

27. Schilder, A.M.C.; Bergstrom, G.C. Infection of Wheat Seed by Pyrenophora tritici-repentis. Can. J. Bot. 1994, 72, 510-519. [CrossRef]

28. See, P.T.; Schultz, N.; Moffat, C.S. Evaluation of Pyrenophora tritici-repentis Infection of Wheat Heads. Agriculture 2020, $10,417$. [CrossRef]

29. Aboukhaddour, R.; Cloutier, S.; Ballance, G.M.; Lamari, L. Genome Characterization of Pyrenophora tritici-repentis Isolates Reveals High Plasticity and Independent Chromosomal Location of ToxA and ToxB. Mol. Plant. Pathol. 2009, 10, 201-212. [CrossRef]

30. Manning, V.A.; Pandelova, I.; Dhillon, B.; Wilhelm, L.J.; Goodwin, S.B.; Berlin, A.M.; Figueroa, M.; Freitag, M.; Hane, J.K.; Henrissat, B.; et al. Comparative Genomics of a Plant-Pathogenic Fungus, Pyrenophora tritici-repentis, Reveals Transduplication and the Impact of Repeat Elements on Pathogenicity and Population Divergence. G3 Genes Genomes Genet. 2013, 3, 41-63. [CrossRef] [PubMed]

31. Moolhuijzen, P.; See, P.T.; Hane, J.K.; Shi, G.; Liu, Z.; Oliver, R.P.; Moffat, C.S. Comparative Genomics of the Wheat Fungal Pathogen Pyrenophora tritici-repentis Reveals Chromosomal Variations and Genome Plasticity. BMC Genomics 2018, $19,279$. [CrossRef]

32. Mundt, C.C. Use of multiline cultivars and cultivar mixtures for disease management. Annu. Rev. Phytopathol. 2002, 40, 381-410. [CrossRef]

33. Mundt, C.C. Durable Resistance: A Key to Sustainable Management of Pathogens and Pests. Infect. Genet. Evol. 2014, 27, 446-455. [CrossRef]

34. Strelkov, S.E.; Lamari, L. Host-Parasite Interactions in Tan Spot [Pyrenophora tritici-repentis] of Wheat. Can. J. Plant. Pathol. 2003, 25, 339-349. [CrossRef]

35. Baloch, F.S.; Alsaleh, A.; Shahid, M.Q.; Çiftçi, V.; de Miera, L.E.S.; Aasim, M.; Nadeem, M.A.; Aktaş, H.; Özkan, H.; Hatipoğlu, R. A Whole Genome DArTseq and SNP Analysis for Genetic Diversity Assessment in Durum Wheat from Central Fertile Crescent. PLoS ONE 2017, 12, e0167821. [CrossRef]

36. Galagedara, N.; Liu, Y.; Fiedler, J.; Shi, G.; Chiao, S.; Xu, S.S.; Faris, J.D.; Li, X.; Liu, Z. Genome-Wide Association Mapping of Tan Spot Resistance in a Worldwide Collection of Durum Wheat. Theor. Appl. Genet. 2020, 133, 2227-2237. [CrossRef] [PubMed] 
37. Gurung, S.; Mamidi, S.; Bonman, J.M.; Jackson, E.W.; del Río, L.E.; Acevedo, M.; Mergoum, M.; Adhikari, T.B. Identification of Novel Genomic Regions Associated with Resistance to Pyrenophora tritici-repentis Races 1 and 5 in Spring Wheat Landraces Using Association Analysis. Theor. Appl. Genet. 2011, 123, 1029. [CrossRef] [PubMed]

38. Halder, J.; Zhang, J.; Ali, S.; Sidhu, J.S.; Gill, H.S.; Talukder, S.K.; Kleinjan, J.; Turnipseed, B.; Sehgal, S.K. Mining and Genomic Characterization of Resistance to Tan Spot, Stagonospora nodorum Blotch (SNB), and Fusarium Head Blight in Watkins Core Collection of Wheat Landraces. BMC Plant. Biol. 2019, 19, 480. [CrossRef]

39. Singh, P.K.; Crossa, J.; Duveiller, E.; Singh, R.P.; Djurle, A. Association Mapping for Resistance to Tan Spot Induced by Pyrenophora tritici-repentis race 1 in CIMMYTs Historical Bread Wheat Set. Euphytica 2016, 207, 515-525. [CrossRef]

40. Lopes, M.S.; El-Basyoni, I.; Baenziger, P.S.; Singh, S.; Royo, C.; Ozbek, K.; Aktas, H.; Ozer, E.; Ozdemir, F.; Manickavelu, A.; et al. Exploiting Genetic Diversity from Landraces in Wheat Breeding for Adaptation to Climate Change. J. Exp. Bot. 2015, 66, 3477-3486. [CrossRef] [PubMed]

41. Mangini, G.; Margiotta, B.; Marcotuli, I.; Signorile, M.A.; Gadaleta, A.; Blanco, A. Genetic Diversity and Phenetic Analysis in Wheat (Triticum Turgidum Subsp. Durum and Triticum Aestivum Subsp. Aestivum) Landraces Based on SNP Markers. Genet. Resour. Crop. Evol. 2017, 64, 1269-1280. [CrossRef]

42. Pignone, D.; de Paola, D.; Rapanà, N.; Janni, M. Single Seed Descent: A Tool to Exploit Durum Wheat (Triticum durum Desf.) Genetic Resources. Genet. Resour. Crop. Evol. 2015, 62, 1029-1035. [CrossRef]

43. Zadoks, J.C.; Chang, T.T.; Konzak, C.F. A decimal code for the growth stages of cereals. Weed Res. 1974, 14, 415-421.

44. Saari, E.E.; Prescott, J.M. Scale for appraising the foliar intensity of wheat diseases. Plant. Dis. Report. 1975, 59, 377-380.

45. Simko, I.; Piepho, H.-P. The Area under the Disease Progress Stairs: Calculation, Advantage, and Application. Phytopathology 2012, 102, 381-389. [CrossRef]

46. R Core Team. R: A Language and Environment for Statistical Computing; R Foundation for Statistical Computing: Vienna, Austria, 2021; Available online: https: / / www.R-project.org/ (accessed on 30 June 2021).

47. Venables, W.N.; Ripley, B.D. Modern Applied Statistics; Fourth, S., Ed.; Springer: New York, NY, USA, 2002; ISBN 0-387-95457-0.

48. Kassambara, A.; Mundt, F. Factoextra: Extract and Visualize the Results of Multivariate Data Analyses; R Package Version 1.0.7; R Foundation for Statistical Computing: Vienna, Austria, 2020; Available online: https: / /CRAN.R-project.org/package=factoextra (accessed on 1 April 2020).

49. Maechler, M.; Rousseeuw, P.; Struyf, A.; Hubert, M.; Hornik, K. Cluster: Cluster Analysis Basics and Extensions; R Package Version 2.1.1; Foundation for Statistical Computing: Vienna, Austria, 2021.

50. Evans, C.K.; Hunger, R.M.; Siegerist, W.C. Comparison of Greenhouse and Field Testing to Identify Wheat Resistant to Tan Spot. Plant. Dis. 1999, 83, 269-273. [CrossRef]

51. Cox, D.J.; Hosford, R.M. Resistant winter wheats compared at differing growth stages and leaf positions for tan spot severity. Plant. Dis. 1987, 71, 883-886. [CrossRef]

52. Tadesse, W.; Reents, H.J.; Hsam, S.L.K.; Zeller, F.J. Relationship of Seedling and Adult Plant Resistance and Evaluation of Wheat Germplasm against Tan Spot (Pyrenophora Tritici-Repentis). Genet. Resour. Crop. Evol. 2011, 58, 339-346. [CrossRef]

53. Perello, A.; Moreno, V.; Simón, M.R.; Sisterna, M. Tan Spot of Wheat (Triticum aestivum L.) Infection at Different Stages of Crop Development and Inoculum Type. Crop. Prot. 2003, 22, 157-169. [CrossRef]

54. Rees, R.G.; Platz, G.J. Effectiveness of incomplete resistance to Pyrenophora tritici-repentis in wheat. Aust. J. Agric. Res. 1989, 40, 43-48. [CrossRef]

55. Gamba, F.M.; Lamari, L.; Brülé-Babel, A.L. Inheritance of Race-Specific Necrotic and Chlorotic Reactions Induced by Pyrenophora tritici-repentis in Hexaploid Wheats. Can. J. Plant. Pathol. 1998, 20, 401-407. [CrossRef]

56. Gamba, F.M.; Lamari, L. Mendelian Inheritance of Resistance to Tan Spot [Pyrenophora tritici-repentis] in Selected Genotypes of Durum Wheat (Triticum turgidum). Can. J. Plant. Pathol. 1998, 20, 408-414. [CrossRef]

57. Lamari, L.; Bernier, C.C. Genetics of tan necrosis and extensive chlorosis in tan spot of wheat caused by Pyrenophora tritici-repentis. Phytopathology 1991, 81, 1092-1095. [CrossRef]

58. Singh, P.K.; Hughes, G.R. Genetic Similarity among Isolates of Pyrenophora tritici-repentis, causal agent of tan spot of wheat. J. Phytopathol. 2006, 154, 178-184. [CrossRef]

59. Singh, P.K.; Mergoum, M.; Gonzalez-Hernandez, J.L.; Ali, S.; Adhikari, T.B.; Kianian, S.F.; Elias, E.M.; Hughes, G.R. Genetics and Molecular Mapping of Resistance to Necrosis Inducing Race 5 of Pyrenophora tritici-repentis in Tetraploid Wheat. Mol. Breed. 2008, 21, 293-304. [CrossRef]

60. Chu, C.-G.; Chao, S.; Friesen, T.L.; Faris, J.D.; Zhong, S.; Xu, S.S. Identification of Novel Tan Spot Resistance QTLs Using an SSR-Based Linkage Map of Tetraploid Wheat. Mol. Breed. 2010, 25, 327-338. [CrossRef]

61. Chu, C.-G.; Friesen, T.L.; Xu, S.S.; Faris, J.D. Identification of Novel Tan Spot Resistance Loci beyond the Known Host-Selective Toxin Insensitivity Genes in Wheat. Theor. Appl. Genet. 2008, 117, 873-881. [CrossRef]

62. Faris, J.D.; Overlander, M.E.; Kariyawasam, G.K.; Carter, A.; Xu, S.S.; Liu, Z. Identification of a Major Dominant Gene for Race-Nonspecific Tan Spot Resistance in Wild Emmer Wheat. Theor. Appl. Genet. 2020, 133, 829-841. [CrossRef]

63. Friesen, T.L.; Faris, J.D. Molecular Mapping of Resistance to Pyrenophora tritici-repentis Race 5 and Sensitivity to Ptr ToxB in Wheat. Theor. Appl. Genet. 2004, 109, 464-471. [CrossRef]

64. Tadesse, W.; Hsam, S.L.K.; Wenzel, G.; Zeller, F.J. Chromosome Location of a Gene Conferring Resistance to Pyrenophora tritici-repentis in Ethiopian Wheat Cultivars. Euphytica 2008, 162, 423-430. [CrossRef] 
65. Tadesse, W.; Schmolke, M.; Hsam, S.L.K.; Mohler, V.; Wenzel, G.; Zeller, F.J. Molecular Mapping of Resistance Genes to Tan Spot [Pyrenophora tritici-repentis race 1] in Synthetic Wheat Lines. Theor. Appl. Genet. 2007, 114, 855-862. [CrossRef]

66. Tadesse, W.; Hsam, S.L.K.; Wenzel, G.; Zeller, F.J. Identification and Monosomic Analysis of Tan Spot Resistance Genes in Synthetic Wheat Lines (Triticum Turgidum L. $\times$ Aegilops Tauschii Coss.). Crop. Sci. 2006, 46, 1212-1217. [CrossRef]

67. Dinglasan, E.G.; Peressini, T.; Marathamuthu, K.A.; See, P.T.; Snyman, L.; Platz, G.; Godwin, I.; Voss-Fels, K.P.; Moffat, C.S.; Hickey, L.T. Genetic Characterization of Adult-Plant Resistance to Tan Spot (Syn, Yellow Spot) in Wheat. Theor. Appl. Genet. 2021, 134, 2823-2839. [CrossRef] [PubMed]

68. Dinglasan, E.G.; Godwin, I.D.; Phan, H.T.T.; Tan, K.-C.; Platz, G.J.; Hickey, L.T. Vavilov Wheat Accessions Provide Useful Sources of Resistance to Tan Spot (Syn. Yellow Spot) of Wheat. Plant. Pathol. 2018, 67, 1076-1087. [CrossRef]

69. Dinglasan, E.; Godwin, I.D.; Mortlock, M.Y.; Hickey, L.T. Resistance to Yellow Spot in Wheat Grown under Accelerated Growth Conditions. Euphytica 2016, 209, 693-707. [CrossRef]

70. Kokhmetova, A.; Sehgal, D.; Ali, S.; Atishova, M.; Kumarbayeva, M.; Leonova, I.; Dreisigacker, S. Genome-Wide Association Study of Tan Spot Resistance in a Hexaploid Wheat Collection from Kazakhstan. Front. Genet. 2021, 11, 581214. [CrossRef]

71. Laribi, M.; Akhavan, A.; M’Barek, S.; Yahyaoui, A.; Strelkov, S.E.; Sassi, K. Characterization of Pyrenophora tritici-repentis in Tunisia and Comparison with a Global Pathogen Population. Plant. Dis. 2021, 107, 2411-2502. [CrossRef]

72. Laribi, M.; Gamba, F.M.; Hassine, M.; Singh, P.K.; Yahyaoui, A.; Sassi, K. Race Structure and Distribution of Pyrenophora tritici-repentis in Tunisia. Phytopathol. Mediterr. 2019, 58, 473-483. [CrossRef]

73. Kamel, S.; Cherif, M.; Hafez, M.; Despins, T.; Aboukhaddour, R. Pyrenophora tritici-repentis in Tunisia: Race Structure and Effector Genes. Front. Plant. Sci. 2019, 10, 1562. [CrossRef] [PubMed]

74. Liu, Z.; El-Basyoni, I.; Kariyawasam, G.; Zhang, G.; Fritz, A.; Hansen, J.; Marais, F.; Friskop, A.; Chao, S.; Akhunov, E.; et al. Evaluation and Association Mapping of Resistance to Tan Spot and Stagonospora Nodorum Blotch in Adapted Winter Wheat Germplasm. Plant. Dis. 2015, 99, 1333-1341. [CrossRef] [PubMed]

75. German, S.E.; Kolmer, J.A. Effect of Gene Lr34 in the Enhancement of Resistance to Leaf Rust of Wheat. Theor. Appl. Genet. 1992, 84, 97-105. [CrossRef] [PubMed]

76. Herrera-Foessel, S.A.; Singh, R.P.; Lillemo, M.; Huerta-Espino, J.; Bhavani, S.; Singh, S.; Lan, C.; Calvo-Salazar, V.; Lagudah, E.S. Lr67/Yr46 Confers Adult Plant Resistance to Stem Rust and Powdery Mildew in Wheat. Theor. Appl. Genet. 2014, 127, 781-789. [CrossRef] [PubMed]

77. Rinaldo, A.; Gilbert, B.; Boni, R.; Krattinger, S.G.; Singh, D.; Park, R.F.; Lagudah, E.; Ayliffe, M. The Lr34 Adult Plant Rust Resistance Gene Provides Seedling Resistance in Durum Wheat without Senescence. Plant. Biotechnol. J. 2017, 15, 894-905. [CrossRef]

78. Bansal, U.K.; Kazi, A.G.; Singh, B.; Hare, R.A.; Bariana, H.S. Mapping of Durable Stripe Rust Resistance in a Durum Wheat Cultivar Wollaroi. Mol. Breed. 2014, 33, 51-59. [CrossRef]

79. Nelson, R.; Wiesner-Hanks, T.; Wisser, R.; Balint-Kurti, P. Navigating Complexity to Breed Disease-Resistant Crops. Nat. Rev. Genet. 2018, 19, 21-33. [CrossRef]

80. Parlevliet, J.E. What is durable resistance, a general outline. In Durability of Disease Resistance; Current Plant Science and Biotechnology in Agriculture; Jacobs, T., Parlevliet, J.E., Eds.; Springer: Berlin/Heidelberg, Germany, 1993; Volume 18, pp. 23-39, ISBN 978-94-010-4885-9.

81. Hotelling, H. Analysis of a Complex of Statistical Variables into Principal Components. J. Educ. Psychol. 1933, 24, 417-441. [CrossRef]

82. Jackson, J.E. A User's Guide to Principal Components; John Wiley and Sons: Hoboken, NJ, USA, 2005; ISBN 978-0-471-72532-9.

83. Li, H.B.; Yan, W.; Liu, G.R.; Wen, S.M.; Liu, C.J. Identification and Validation of Quantitative Trait Loci Conferring Tan Spot Resistance in the Bread Wheat Variety Ernie. Theor. Appl. Genet. 2011, 122, 395-403. [CrossRef]

84. Muqaddasi, Q.H.; Kamal, R.; Mirdita, V.; Rodemann, B.; Ganal, M.W.; Reif, J.C.; Röder, M.S. Genome-Wide Association Studies and Prediction of Tan Spot (Pyrenophora tritici-repentis) Infection in European Winter Wheat via Different Marker Platforms. Genes 2021, 12, 490. [CrossRef] [PubMed]

85. Kollers, S.; Rodemann, B.; Ling, J.; Korzun, V.; Ebmeyer, E.; Argillier, O.; Hinze, M.; Plieske, J.; Kulosa, D.; Ganal, M.W.; et al. Genome-Wide Association Mapping of Tan Spot Resistance (Pyrenophora tritici-repentis) in European Winter Wheat. Mol. Breed. 2014, 34, 363-371. [CrossRef]

86. Kollers, S.; Rodemann, B.; Ling, J.; Korzun, V.; Ebmeyer, E.; Argillier, O.; Hinze, M.; Plieske, J.; Kulosa, D.; Ganal, M.W.; et al Whole Genome Association Mapping of Fusarium Head Blight Resistance in European Winter Wheat (Triticum aestivum L.). PLoS ONE 2013, 8, e57500. [CrossRef]

87. Spanic, V.; Lemmens, M.; Drezner, G.; Dvojkovic, K. Interrelations between height of winter wheat genotypes and resistance to Fusarium head blight (fhb). Rom. Agric. Res. 2011, 28, 43-48.

88. Mao, S.L.; Wei, Y.M.; Cao, W.; Lan, X.J.; Yu, M.; Chen, Z.M.; Chen, G.Y.; Zheng, Y.L. Confirmation of the Relationship between Plant Height and Fusarium Head Blight Resistance in Wheat (Triticum aestivum L.) by QTL Meta-Analysis. Euphytica 2010, 174, 343-356. [CrossRef]

89. Wicki, W.; Winzeler, M.; Schmid, J.E.; Stamp, P.; Messmer, M. Inheritance of Resistance to Leaf and Glume Blotch Caused by Septoria Nodorum Berk in Winter Wheat. Theor. Appl. Genet. 1999, 99, 1265-1272. [CrossRef] 
90. Tavella, C.M. Date of Heading and Plant Height of Wheat Varieties, as Related to Septoria Leaf Blotch Damage. Euphytica 1978, 27, 577-580. [CrossRef]

91. Danon, T.; Sacks, J.M.; Eyal, Z. The relationships among plant stature, maturity class, and susceptibility to Septoria leaf blotch of wheat. Phytopathology 1982, 72, 1037-1042. 